\title{
Gambaran Kejadian Diare Akibat Infeksi Protozoa Usus pada Pasien Kemoterapi di RSUP Dr. M. Djamil Padang
}

\author{
Putri Awaliyah Deza ${ }^{1}$, Eka Nofita $^{2}$, Adrial $^{2}$
}

\begin{abstract}
Abstrak
Kecenderungan pasien kemoterapi untuk terpapar infeksi parasit sangat tinggi. Infeksi parasit pada pasien immunocompromised lebih sering ditemukan dengan diare dibandingkan pasien imunokompeten. Salah satu infeksi parasit yang sering ditemukan pada pasien kemoterapi adalah protozoa usus. Tujuan penelitian ini adalah menentukan gambaran kejadian diare akibat infeksi protozoa usus pada pasien kemoterapi di RSUP Dr. M. Djamil Padang. Jenis penelitian ini adalah penelitian deskriptif dengan jumlah subjek sebanyak 59 orang. Data didapatkan dari analisis feses dan rekam medik. Pengolahan data dilakukan secara manual dan disajikan dalam bentuk tabel distribusi frekuensi. Teknik pengambilan sampel yang digunakan adalah consecutive sampling. Hasil penelitian menunjukkan bahwa angka kejadian protozoa usus pada pasien kemoterapi sebesar 6.7\%, 75\% diantaranya menderita diare dan semuanya merupakan diare akut. Semua diare disebabkan oleh Entamoeba histolytica dan terbanyak muncul pada siklus kedua (67\%). Simpulan penelitian ini adalah sebagian besar pasien kemoterapi yang terinfeksi protozoa usus mengalami diare dan spesies penyebabnya adalah Entamoeba histolytica.
\end{abstract}

Kata kunci: protozoa usus, diare, pasien kemoterapi

\begin{abstract}
The tendency of chemotherapy patients to be exposed to parasitic infections is high. Parasitic infections on immunocompromised patients often appeared with diarrhea than immunocompetent patients. One of the parasitic infections, which is found frequently on chemotheraphy patients is intestinal protozoa. The objective of this study was to determine the incidence of diarrhea due to intestinal protozoa infections in chemotheraphy patients in Dr.M. Djamil Padang Hospital. The method used in this research was descriptive research on fifty nine subjects. All data were obtained from the fecal analysis and medical records. Data were processed manually and presented in distribution and frequency table. The sampling technique was consecutive sampling. The results showed that the number of protozoa intestinal events on chemotheraphy patients were $6.7 \%, 75 \%$ of them suffered diarrhea and categorized as acute diarrhea. All diarrhea were caused by Entamoeba histolytica and mostly appeared on second cycle (67\%). The results of this research indicate that most of chemotheraphy patients that infected by intestinal protozoa have diarrhea and the species of protozoa which cause diarrhea is Entamoeba histolytica.
\end{abstract}

Keywords: intestinal protozoa, diarrhea, chemotheraphy patients

Affiliasi penulis: 1. Prodi Kedokteran Fakultas Kedokteran Universitas Andalas Padang (FK Unand), 2. Bagian Parasitologi FK Unand

Korespondensi: Putri Awaliyah Deza, Email:

putriawaliyahdeza@gmail.com Telp: 082284567956

\section{PENDAHULUAN}

Infeksi protozoa usus masih menjadi salah satu permasalahan di dunia, terutama di negara-negara berkembang dan beriklim tropis. Di Indonesia, angka insidensi kasus protozoa usus mencapai 10-18\%. Infeksi protozoa usus dapat menyerang siapa saja, 
baik penderita yang imunokompeten maupun pasien dengan gangguan imun (immunocompromised). Kejadian infeksi pada pasien immunocompromised lebih banyak ditemukan dan umumnya gejala yang timbul akan lebih berat dibandingkan penderita imunokompeten. ${ }^{1}$

Salah satu pasien immunocompromised yang sering luput dari perhatian tenaga kesehatan adalah pasien kanker yang sedang menjalani kemoterapi. Berdasarkan hasil Riskesdas 2013, prevalensi kanker di Indonesia meningkat seiring pertambahan usia. Kanker pada perempuan cenderung lebih tinggi daripada laki-laki. $^{2}$

Kanker adalah pertumbuhan sel atau jaringan yang tidak terkendali akibat mutasi gen tertentu. Penurunan imun pada pasien yang mendapat pengobatan kemoterapi disebabkan karena tidak adekuatnya respon imun humoral dan seluler. Rendahnya jumlah sel T CD4 dan sel T sitotoksik sebagai pengeliminasi antigen serta pendeknya memori sel $\mathrm{T}$ humoral dalam mengingat antigen yang masuk menjadi pemicu tingginya insidensi penyakit berbasis infeksi pada penderita kanker. Akibat proses diatas, pasien kemoterapi rentan terkena infeksi. ${ }^{3}$

Kecenderungan pasien kemoterapi untuk terpapar infeksi parasit sangat tinggi, umumnya outcome yang muncul sangat berat. Diare merupakan penyakit komorbid yang sering dijumpai pada pasien kemoterapi. Infeksi parasit yang menyebabkan diare pada pasien immunocompromised lebih sering ditemukan dibandingkan pasien imunokompeten. Gejala penyerta yang timbul berupa kehilangan berat badan, anoreksia, sindrom malabsorpsi, dan dalam beberapa kasus ditemukan demam dan sakit perut. ${ }^{4}$

Pada tahun 2010, hasil penelitian di Perancis oleh Anane et al menyebutkan bahwa 13 dari 14 pasien immunocompromised yang menderita mikrosporidiosis memunculkan gejala klinis yang nyata. Gejala dengan frekuensi terbanyak adalah diare (11 kasus), dan terkadang diikuti dengan dehidrasi (5 kasus). ${ }^{5}$

Penelitian lainnya di Mesir oleh Abdel-Magied et al pada tahun 2016 menyatakan bahwa protozoa usus terdeteksi sebanyak $85,5 \%$ pada sampel tinja pasien kemoterapi. Protozoa Giardia lamblia $(36,6 \%)$,
Cryptosporidium parvum (30,3\%) dan Entamoeba histolytica $(27,6 \%)$ merupakan jenis parasit yang paling banyak ditemukan. Infeksi parasit ini erat kaitannya dengan diare tipe persisten. ${ }^{6}$

Neha Ballani et al di India pada tahun 2012, $38 \%$ sampel tinja pasien kemoterapi positif mengandung organisme parasit. Beberapa protozoa usus seperti Cryptosporidium sp. dan E. histolytica merupakan jenis parasit terbanyak yang menginfeksi pasien kemoterapi, yakni masing-masing sebesar $39,5 \%$. $^{4}$

Berdasarkan pelacakan yang dilakukan oleh peneliti, belum ditemukan penelitian mengenai gambaran kejadian diare akibat protozoa usus pada pasien kemoterapi di Indonesia. Oleh karena itu, perlu untuk dilakukan penelitian tersebut. RSUP Dr.M.Djamil menjadi pilihan lokasi penelitian ini dikarenakan RSUP Dr.M.Djamil merupakan rumah sakit rujukan dalam tatalaksana lanjutan kanker.

\section{METODE}

Jenis penelitian ini adalah deskriptif yang dilakukan dari Februari sampai April 2018. Penelitian ini dilaksanakan di RSUP Dr. M. Djamil Padang sebagai tempat pengambilan sampel dan Laboratorium Departemen Parasitologi FK Unand dipilih sebagai lokasi pemeriksaan sampel yang didapatkan dari pasien kemoterapi.

Populasi dari penelitian ini adalah pasien yang sedang menjalani kemoterapi di RSUP Dr.M. Djamil yang keseluruhannya berjumlah 143 orang.

Besar sampel didapatkan sebanyak 59 sampel yang dipilih dengan teknik consecutive sampling. Sampel penelitian adalah semua pasien kanker yang sedang menjalani pengobatan kemoterapi dan memenuhi kriteria inklusi dan kriteria eksklusi. Kriteria inklusi subjek ini adalah semua pasien kanker yang mendapat kemoterapi di unit kemoterapi RSUP Dr. M Djamil Padang, telah menjalani minimal satu kali siklus kemoterapi dan bersedia menjadi sampel penelitian. Kriteria eksklusi adalah dalam dua kali kunjungan tidak didapatkan sampel feses serta menjalani pengobatan radioterapi sebagai salah satu pengobatan kanker.

Data diperoleh dari analisis feses dan rekam medik. Hasil untuk analisis feses didapatkan dengan 
pemeriksaan mikroskopis berupa pemeriksaan tinja langsung dan pewarnaan modifikasi Ziehl-Neelsen. Pemeriksaan tinja langsung dapat dilakukan untuk mendeteksi E. histolytica, G. lamblia, dan Blastocystis hominis. Pemeriksaan tinja dengan pewarnaan modifikasi Ziehl-Neelsen dapat digunakan untuk mendeteksi Cryptosporidium dan Isospora belli.

\section{HASIL}

Subjek dari penelitian ini adalah 59 pasien kemoterapi yang dipilih berdasarkan kriteria inklusi dan eksklusi.

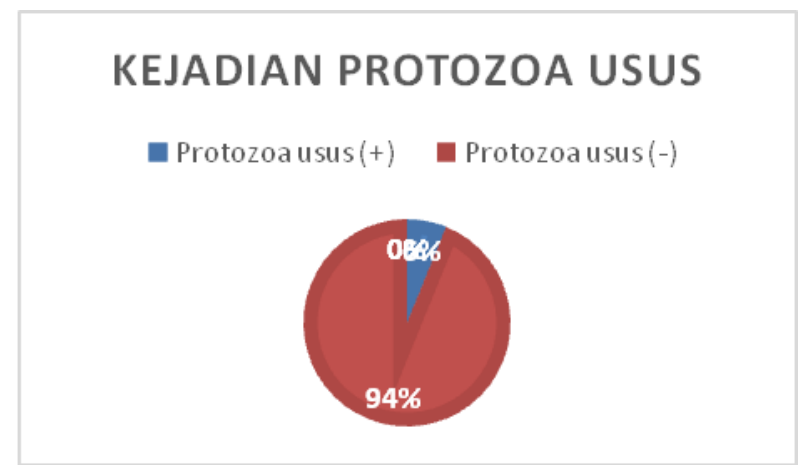

Gambar 1. Distribusi frekuensi angka kejadian protozoa usus pada pasien kemoterapi di RSUP Dr. M. Djamil Padang

Gambar 1 memperlihatkan angka kejadian protozoa usus pada sampel feses pasien kemoterapi yang diperiksa. Dari 59 sampel yang diperiksa, didapatkan persentase kejadian sebanyak empat kasus $(6.7 \%)$.

\section{KEJADIAN DIARE}

- Diare -Tidak diare

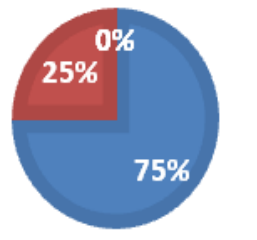

Gambar 2. Distribusi frekuensi angka kejadian diare pada infeksi protozoa usus pada pasien kemoterapi di RSUP Dr.M Djamil Padang
Gambar 2 memperlihatkan angka kejadian diare pada sampel feses pasien kemoterapi yang diperiksa. Berdasarkan tabel 4.2, kejadian diare pada pasien yang terinfeksi protozoa usus didapatkan sebanyak 3 kasus (75\%).

\section{DIARE}

\section{akut a Persisten Kronik}

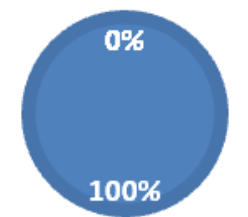

Gambar 3. Distribusi Frekuensi Kejadian Diare Berdasarkan Klasifikasi Waktunya

Gambar 3 memperlihatkan hasil bahwa diare tipe akut diderita oleh semua pasien, yakni sebanyak 3 kasus (100\%). Lama berlangsungnya diare bervariasi pada setiap pasien (berkisar antara 2-4 hari).

Tabel 4. Distribusi frekuensi kejadian diare berdasarkan spesies pada pasien kemoterapi di RSUP DR.M Djamil

\begin{tabular}{llllll}
\hline \multirow{2}{*}{ Jenis parasit } & \multicolumn{2}{c}{ Diare (+) } & \multicolumn{2}{c}{ Diare (-) } & \multirow{2}{*}{ Total } \\
\cline { 2 - 5 } & $\mathrm{f}$ & $\%$ & $\mathrm{f}$ & $\%$ & \\
\hline $\begin{array}{l}\text { Entamoeba } \\
\text { histolytica }\end{array}$ & 3 & 100 & 0 & 0 & 3 \\
$\begin{array}{l}\text { Cryptosporidium } \\
\text { Giardia lamblia }\end{array}$ & 0 & 0 & 1 & 100 & 1 \\
Blastocystis hominis & 0 & 0 & 0 & 0 & 0 \\
Isospora belli & 0 & 0 & 0 & 0 & 0 \\
\hline Total & 3 & 100 & 1 & 100 & 4 \\
\hline
\end{tabular}

Berdasarkan hasil pada Tabel 4 disimpulkan bahwa semua kejadian diare muncul pada pasien yang terinfeksi Entamoeba histolytica, yakni sebanyak 3 kasus (100\%).

\section{PEMBAHASAN}

Berdasarkan penelitian yang telah dilakukan dari Februari sampai April 2018, telah diambil 59 sampel feses dari pasien yang sedang menjalani kemoterapi di Unit Kemoterapi RSUP Dr. M. Djamil 
Padang. Empat dari 59 sampel feses yang diperiksa (6.7\%), positif mengandung protozoa usus. Adapun spesies protozoa yang menginfeksi adalah Entamoeba histolytica sebanyak tiga kasus dan Cryptosporidium sp.sebanyak satu kasus.

Hasil yang didapatkan penelitian ini sebanding dengan yang didapatkan oleh Kaleiselvam di Medan yang menyatakan bahwa tiga dari 38 (7.9\%) sampel tinja pasien kanker dewasa positif mengandung protozoa usus. Satu sampel feses ditemukan ookista Cryptosporidium, sedangkan dua sampel lainnya ditemukan kista E. histolytica. ${ }^{7}$ Pada tahun 2010, Baiomy et al menemukan bahwa kejadian parasit lebih banyak terjadi pada pasien dengan gangguan imunitas dibandingkan yang imunokompeten, yakni sebanyak $30 \%{ }^{8}$

Adanya gangguan pada fungsi sel $\mathrm{T}$ pasien dengan imunitas rendah, termasuk pasien yang sedang menjalani pengobatan kemoterapi, mengakibatkan pasien tersebut memiliki risiko tinggi untuk terkena infeksi. Menurut mekanismenya, protozoa usus akan memicu respon imun adaptif yang dimediasi oleh sel T. Akan tetapi, respon yang diberikan oleh sel T tidak selalu efektif. Akibatnya, protozoa mampu menghindari respon imun dan bertahan dalam sel inang. ${ }^{9}$ Infeksi protozoa usus pada pasien kemoterapi tidak hanya disebabkan oleh faktor imun saja. Faktor lain yang dapat memicu infeksi tersebut adalah sumber air minum yang tidak bersih, buang air besar di sungai dan rawa, mandi dan sikat gigi dengan air sungai atau rawa, buruknya kebersihan pribadi, serta adanya kontak dengan hewan yang terinfeksi protozoa. $^{1,10}$ Pada penelitian ini, peneliti tidak memerhatikan hal-hal tersebut.

Berdasarkan penemuan yang didapatkan oleh peneliti, terdapat tiga kasus diare dari empat sampel feses $(75 \%)$ yang positif mengandung protozoa usus. Frekuensi diare yang dialami oleh penderita perharinya bervariasi antar satu sama lain. Ada yang mengeluhkan lebih dari empat kali dan lebih dari enam kali sehari. Selain itu, dari pemeriksaan makroskopis, konsistensi feses berbentuk cair dan dua kasus diantaranya disertai lendir.

Hasil yang didapatkan oleh peneliti lebih tinggi dibandingkan dengan penelitian Arikan et al dan
Guarner et al. Penelitian yang dilakukan Arikan et al di Turki menyatakan bahwa $45 \%$ pasien dengan penurunan imun mengalami diare. Penelitian lainnya yang dilakukan oleh Guarner et al di Mexico menyatakan bahwa $26 \%$ dari sampel diare pasien kanker positif mengandung parasit. E. histolytica merupakan jenis parasit yang paling banyak ditemukan. $^{10,11}$

Penemuan peneliti ini sesuai dengan literatur yang ditulis oleh Herbowo yang menyatakan bahwa diare menjadi salah satu manifestasi yang sering ditemukan pada penderita yang terinfeksi parasit, baik protozoa usus maupun cacing. ${ }^{12}$ Faktor agen, penjamu dan lingkungan berperan secara langsung maupun tidak langsung dalam menentukan tinggi rendahnya kasus diare. Faktor penjamu dapat menyebabkan tingginya kerentanan terhadap diare, misalnya status nutrisi yang buruk dan imunodefisiensi. Faktor lingkungan yang juga ikut berperan adalah sumber air yang tidak sehat, rendahnya kesadaran personal untuk menerapkan PHBS serta pembuangan tinja yang tidak dilakukan secara tepat. $^{13}$

Diare diklasifikasikan menjadi diare akut, persisten dan kronis. Diare akut berlangsung selama kurang dari dua minggu. ${ }^{14}$ Diare persisten adalah diare akut yang terjadi secara terus menerus selama lebih dari dua minggu. Sedangkan diare kronis secara umum diartikan sebagai gejala diare yang muncul lebih dari 30 hari. $^{15}$

Pada penelitian ini, semua kasus diare yang diderita oleh pasien dikategorikan dalam diare tipe akut (100\%). Pasien mengeluhkan diare berlangsung selama dua hingga empat hari dengan frekuensi yang berbeda setiap harinya.

Hasil yang didapatkan peneliti sebanding dengan penelitian Sreedharan et al pada pasien kanker yang mengalami diare di India. Ookista Cryptosporidium ditemukan pada tujuh sampel feses (1.3\%) terperiksa. Dari tujuh kasus, lima kasus (71\%) diantaranya merupakan diare akut dan dua lainnya (29\%) adalah diare kronik. $^{16}$ Namun, hasil yang ditemukan oleh peneliti sangat berbeda dengan hasil yang didapatkan dari penelitian sebelumnya. Pada tahun 2016, Serhat Uysal et al di Turki memeriksa 26 sampel diare pasien dengan penurunan imun. 
Sebanyak 50\% diantaranya positif mengandung protozoa usus. Uysal et al juga menambahkan bahwa diare pada pasien yang terinfeksi protozoa ini berlangsung lebih lama dibandingkan diare infeksius lainnya, yakni sekitar 16.2 hari. $^{17}$

Adanya perbedaan pada durasi diare dapat dikaitkan dengan jumlah CD4 pasien. Pasien dengan diare kronis memiliki jumlah CD4 yang lebih rendah dibandingkan pasien dengan diare akut. ${ }^{18}$ Secara umum, pemberian kemoterapi mengakibatkan turunnya imun penderita akibat supresi pada sumsum tulang belakang. Walaupun demikian, respon yang diterima oleh pasien tidaklah sama. Hal ini seperti yang diutarakan oleh Agung Waluyo. ${ }^{19}$

Berdasarkan pemeriksaan mikroskopis, tiga sampel feses yang disertai diare mengandung protozoa jenis E. histolytica (100\%). Sedangkan satu sampel yang tidak disertai diare mengandung protozoa jenis Cryptosporidium (100\%).

Hasil yang didapatkan oleh peneliti hampir sama dengan hasil dari penelitian Botero et al dan AlMegrin. Terdapat kesamaan spesies protozoa yang sering menginfeksi pada diare, yakni E. histolytica dan Cryptosporidium. Botero menyatakan bahwa spesies protozoa usus terbanyak yang ditemukan pada $52.3 \%$ sampel feses diare pasien dengan penurunan imun adalah E. histolytica sebanyak $9.91 \% .^{20}$ Penelitian lainnya yang dilakukan oleh Al-Megrin menyatakan bahwa $39.7 \%$ sampel feses pasien dengan penurunan imun positif mengandung parasit dan 25.7\% diantaranya disertai dengan diare. Adapun spesies penginfeksi yang ditemukan adalah Cryprosporidium sebanyak $8.1 \%$, G. lamblia sebanyak $6.6 \%$, B. hominis dan E. histolytica sebanyak $5.2 \%{ }^{21}$

Infeksi Cryptosporidium dapat muncul dengan atau tanpa diare. Penelitian yang dilakukan oleh Kalantari et al membuktikan hal tersebut. Sebanyak 4.03\% sampel positif yang ditemukan disertai dengan diare, sedangkan $1.1 \%$ sampel positif tidak disertai diare. $^{22}$ Berat atau ringannya munculan gejala yang timbul dapat disebabkan karena beberapa faktor, seperti lokasi infeksi, status nutrisi dan imun penderita, serta faktor lain terkait parasit (parasite-related factors). ${ }^{23}$
Rerata munculan diare pada infeksi protozoa usus terbanyak pada siklus kedua (67\%). Dari tiga kasus diare yang ditemukan, dua kasus timbul pada siklus kedua, sedangkan pada siklus kelima hanya satu kasus saja. Adanya perbedaan antara munculan diare pada ketiga kasus diatas mungkin disebabkan karena tingkat imunitas seseorang berbeda.

Penelitian yang dilakukan oleh Ariawati et al menyimpulkan bahwa terdapat penurunan jumlah leukosit pada pasien Leukemia Limfoblastik Akut (LLA) setelah pemberian regimen kemoterapi pada fase induksi. Rendahnya kadar leukosit, terutama bila jumlah granulosit $\leq 1000 / \mu \mathrm{L}$, dapat meningkatkan risiko terjadinya infeksi. Pada penelitian ini, kadar terendah leukosit, yakni sebanyak 500/ $\mathrm{L}$, terjadi setelah pemberian kemoterapi yang pertama dan kedua. ${ }^{24,25}$

Berdasarkan review yang dibuat oleh Jomar et al di Brazil pada tahun 2017, risiko infeksi termasuk ke dalam permasalahan keperawatan yang sering muncul (2/4) pada pasien yang sedang dalam pengobatan antineoplasma (kemoterapi). Hal ini dikarenakan, pengobatan tersebut menyebabkan terjadinya imunosupresi. Akibatnya, risiko infeksi yang dapat timbul pada pasien semakin tinggi. ${ }^{26}$

Tingginya risiko infeksi pada pasien kanker disebabkan karena adanya perubahan pada sistem pertahanan tubuh. Perubahan tersebut dapat disebabkan oleh kanker itu sendiri, jenis pengobatan kanker yang dilakukan, serta nutrisi yang buruk. Ketiga faktor diatas akan memengaruhi jumlah sel darah putih sehingga meningkatkan risiko infeksi pada pasien. ${ }^{27}$

\section{SIMPULAN}

Spesies protozoa usus yang ditemukan pada penderita diare semuanya adalah Entamoeba histolytica. Kasus diare pada protozoa usus lebih banyak timbul pada siklus kedua

\section{DAFTAR PUSTAKA}

1. Anorital, Dewi RM, Ompusunggu S. Distribusi parasit usus protozoa di kabupaten hulu sungai utara kalimantan selatan. Suplemen Media Penelitian dan Kesehatan. 2010;XX:S8-18. 
2. Badan Penelitian dan Pengembangan Kesehatan Kementrian Kesehatan RI. Riset kesehatan dasar 2013. Jakarta: Badan Penelitian dan Pengembangan Kesehatan Kementrian Kesehatan RI; 2013.hlm.85-6.

3. Solomayer EF, Feuerer M, Bai L, Umansky V, Beckhove P, Meyberg GC, et al. Influence of adjuvant hormone therapy and chemotherapy on the immune system analysed in the bone marrow of patients with breast cancer. Clinical Cancer Research. 2003 Jan;9:174-80.

4. Ballani N, Shujatullah F, Khan HM, Malik A, Ali MASM, Khan PA. Intestinal protozoa in immunosuppression: a medical hassle. J Bacteriol Parasitol. 2012;May 3(3):1-5.

5. Anane S, Attouchi H, Kaouech E, Belhadj S, Chaabane TB, Abdallah NB, et al. Epidemiological and clinical characteristics of intestinal microsporidiosis. Sante. 2010;20(1);21-9.

6. Abdel-Magied AA, El-Ghanam WA, El-Nemr HI, ElHenawy AA. Prevalence of intestinal parasites in cancer therapy recipients with concurrent diarrhea. IJTDH. 2016;15(1):1-7.

7. Kaleiselvam R. Prevalensi infeksi protozoa usus pada pasien kanker di RSUP Haji Adam Malik Medan (skripsi). Medan: Universitas Sumatera Utara; 2010.

8. Baiomy AM, Mohamed KA, Ghannam MA, Shahat SA, Al-Saadawy AS. Opportunistic parasitic infections among immunocompromised Egyptian patients. J Egypt Soc Parasitol. 2010;40(3):797808.

9. Marcos LA, Gotuzzo E. Intestinal protozoan infections in the immunocompromised host. Curr Opin Infect Dis. 2013;26(4):295-301.

10. Arikan $S$, Ergüven $S$, Akyön $Y$, Günalp $A$. Cryptosporidiosis in immunocompromised patients in a Turkish university hospital. Acta Microbiol Immunol Hung.1999;46(1):33-40.

11. Guarner J, Matilde-Nava T, Villasenor-Flores R, Sanchez-Mejorada G. Frequency of intestinal parasites in adult cancer patients in Mexico. Arch Med Res.1997;28(2):219-22.

12. Herbowo FA. Diare akibat infeksi parasit. Sari Pediatri. 2003;4(4):198-203.
13. Rahmadian S, Ketaren O, Sirait A. Faktor-faktor yang berhubungan dengan kejadian diare di puskesmas perawatan ngkeran kabupaten aceh tenggara pada tahun 2017. Jurnal IImiah Simantek.2017;1(2):87-92.

14. Manatsathit S, Dupont HL, Farthing M. Guideline for the management of acute diarrhea in adults. Journal of Gastroenterology and Hepatology. 2002;17 Suppl:S54-S71.

15. Riddle MS, Dupont HL, Connor BA. ACG clinical guideline: diagnosis, treatment, and prevention of acute diarrheal infections in adults. The American Journal of Gastroenterology. 2016; Mar 11:602-22.

16. Sreedharan A, Jayshree RS, Sridhar $H$. Cryptosporidiosis among cancer patients: an observation. J Diarrhoeal Dis Res.1996;14(3): 211-3.

17. Uysal S, Tunal V, Öztürk EA, Ardeniz Ö, Işıkgöz Taşbakan M, Pullukçu $\mathrm{H}$, et al. Incidence of parasitic diarrhea in patients with common variable immune deficiency. Turkiye Parazitol Derg. 2016; 40: 67-71.

18. Tuli L, Gulati AK, Sundar S, Mohapatra TM. Correlation between CD4 counts of HIV patients and enteric protozoan in different seasons - An experience of a tertiary care hospital in Varanasi (India). BMC Gastroenterol. 2008:36;1-6.

19. Waluyo A. Analisis masalah keperawatan pada klien keganasan hematologi yang mendapatkan terapi medik kemoterapi. J Keperawatan Indones. 2000;8(1):1-7.

20. Botero JH, Castaño A, Montoya MN, Ocampo NE, Hurtado MI, Lopera MM. A preliminary study of the prevalence of intestinal parasites in immunocompromised patients with and without gastrointestinal manifestations. Inst Med trop. 2003;45(4):197-200.

21. Al-Megrin WAI. Intestinal parasites infection among immunocompromised patients in Riyadh, Saudi Arabia. Pak J Biol Sci. 2010;13(8):390-4.

22. Kalantari N, Ghaffari S, Bayani M. Cryptosporidium spp. infection in Iranian children and immunosuppressive patients: A systematic review and meta-analysis. Caspian $J$ Intern Med. 2018;9(2):106-15. 
23. Chalmers RM, Davies AP. Minireview: Clinical cryptosporidiosis. Experimental Parasitology. 2010;124(1):138-46.

24. Ariawati K, Windiastuti E, Gatot D. Toksisitas kemoterapi leukemia limfoblastik akut pada fase induksi \& profilaksis susunan saraf pusat dengan metotreksat 1 gram. Sari Pediatri.2007;9(4):252-8.

25. American Cancer Society. Understanding your lab test result. 2016 (diunduh 17 Mei 2018). Tersedia dari https://www.cancer.org/treatment/ understanding-your-diagnosis/tests/understandingyour-lab-test-results.html.
26. Jomar RT, Gomes RAF, Leite DC, Gomes HF, Peres EM, Junior EFP. Nursing diagnoses in adult/elderly patients undergoing outpatient antineoplastic chemotherapy: A review. E Cancer Medical Science. 2017;11:1-10.

27. American Cancer Society. What makes people with cancer more likely to get infection?. 2016 (diunduh 17 Mei 2018). Tersedia dari https://www.cancer. org/treatment/treatments-and-side-effects/physicalside-effects/infections/infections-in-people-withcancer/why-people-with-cancer-are-at-risk.html. 